\title{
Organisational Commitment, Work Engagement and Job Performance: Empirical Study on Nigeria's Public Healthcare System
}

\author{
Ismaheel Adewumi RAJI \\ Department of Business Management, ABU Business School \\ Ahmadu Bello University \\ Zaria, Kaduna State, Nigeria \\ Email: dewumi07@gmail.com \\ Sahnun LADAN \\ Department of Business Management, ABU Business School \\ Ahmadu Bello University \\ Zaria, Kaduna State, Nigeria \\ Email: sahnunl@yahoo.com \\ Md. Mahmudul ALAM * \\ School of Economics, Finance and Banking \\ Universiti Utara Malaysia \\ Sintok, Kedah State, Malaysia \\ Email: rony000@gmail.com

\section{Isma'il Tijjani IDRIS} \\ Department of Banking and Finance, ABU Business School \\ Ahmadu Bello University \\ Zaria, Kaduna State, Nigeria \\ Email: ismaildel@yahoo.com \\ * corresponding author
}

\section{Citation Reference:}

Raji, I.A., Ladan, S., Alam, M.M. \& Idris, I.T. (2021). Organisational Commitment, Work Engagement and Job Performance: Empirical Study on Nigeria's Public Healthcare System. Journal for Global Business Advancement, 14(1). 115-137. (online) http://dx.doi.org/10.1504/IJESD.2021.112666

This is a pre-publication copy.

The published article is copyrighted by the publisher of the journal. 


\title{
Organisational Commitment, Work Engagement and Job Performance: Empirical Study on Nigeria's Public Healthcare System
}

\begin{abstract}
Currently, nurses' job performance in Nigeria's public healthcare system has been called into question and is under more pressure due to the current global COVID-19 pandemic. In enhancing the effectiveness, efficiency and promptness of Nigeria's public healthcare service delivery, this study seeks to explore how work engagement could play a key role in explaining the influence of organisational commitment on nurses' job performance. A survey-based questionnaire, using a simple random technique was employed to collect data from 406 nurses working in public hospitals in Kaduna State, Nigeria. The data were analysed employing the Partial Least Squares-Structural Equation Model (PLS-SEM). Results demonstrate that affective and normative commitment wield positive significant effects on nurses' job performance, while work engagement significantly mediates affective commitment, normative commitment and nurses' job performance relationships. Consequently, this study recommends that the management of Nigeria's public healthcare system and its policymakers should improve the commitment level of nurses through work engagement with a view to enhancing how well they do their job. This study benefits all the relevant stakeholders of Nigeria's public healthcare system.
\end{abstract}

Keywords: Organisational Commitment, Work Engagement, Job Performance, Public Healthcare System, Nigeria

\section{Introduction}

Any organisation wanting to be successful should pay close attention to employees' job performance since they are the foundation upon which other resources are built and developed. It is required of organisations that they effectively manage their employees, so they produce their best work (Campbell \& Wiernik, 2015; Ismail, Iqbal \& Nasr, 2018) As contended by Shahzadi (2014), organisational success greatly depends on employee performance; this is a key mechanism to achieving an institution's goals. It is considered to be a pervasive variable in the organisational and industrial literature (Prasetya \& Kato, 2011; Ngwenya \& Pelser, 2020; Wang \& Chen, 2019). In this sense, Gibson (2012) views ideal employee job performance as being the most effective and efficient way to complete a task so that the worker and employer are both satisfied. Specifically, employee job performance entails workers' timeliness, attendance/presence at the job, producing consistently good quality outcomes, and being efficient and effective (Mathis \& Jackson, 2009; Nmadu; 2013).

In the healthcare system, nurses' job performance is crucial to the overall achievement of the system where promptness, efficiency and effectiveness are of significance. However, it is the case that nurses encounter numerous challenges and problems ranging from work overloads, long hours, poor or stressed state of well-being, poor salaries/wages for the work that they do, resulting in a low level of commitment to the workplace and consequently poor performance (Gile, Samardzic \& Klundert, 2018). Currently, nurses are compromised in their ability to save lives in the fight against the devastating COVID-19 pandemic which has led to the deaths of many nurses (World Health Organization, 2020). With specific reference to Nigeria's healthcare system, the performance of nurses has been called into question as many of them are underperforming. Quite a number of patients have experienced poor healthcare service delivery outcomes in the country's public hospitals (Kuye \& Akinwale, 2020). Subsequently, 
understanding the antecedents of nurses' poor job performance is vital to overall healthcare success and service delivery.

Organisational commitment, however, comprises a variety of job-related attitudes that interest researchers in the area of Human Resource Management (HRM) (Robberts, van der Poll \& Engelbrecht, 2020), and has been noted as greatly influencing employees' and organisational performance (Kaplan \& Kaplan, 2018; Robbins, 2005). Organisational commitment is viewed as a psychological attachment of people to their workplace, and it encapsulates a belief in and loyalty to its values, mission and goals. It is a multi-dimensional construct that revolves around employees' proclivity to exert effort, acceptance of organisations' values and goals, and wanting to keep working there (Al Zeifeti \& Mohamad, 2017; Maleka et al., 2019; Jang \& Kandampully, 2018).

Various scholars over the years (e.g., Krishnaveni \& Ramkumar, 2008; Meyer \& Herscovitch, 2001; Meyer, Becker \& Vandenberghe, 2004) have argued that organisational commitment might be difficult to understand if it is conceived as a uni-dimensional construct. They further posit that an adequate understanding of organisational commitment requires a multifaceted approach. As such, quite a number of scholars allude support for the multifaceted approach to organisational commitment (Jang \& Kandampully, 2018; Hafiz, 2017; Putri \& Setianan, 2019). Based on this theme, this study adopts a three-dimensional approach to organisational commitment as proposed by Meyer and Allen (1991). Apart from this, studies on organisational commitment and employees' job performance still remain inconclusive because some empirical research has found that organisational commitment may not necessarily bring about optimum performance unless it is related to work itself (Cesário \& Chambel, 2017; Hanaysha, 2016). There have been reported cases of inconsistent or ambiguous results in the extant literature (Adrianto \& Riyanto, 2020; Pratama \& Aima, 2018). These kinds of results show there is no clear-cut connection between organisational commitment and employee performance. As such, there seems to be a missing link which necessitates further investigation and explanation of the nexus between organisational commitment and employee job performance.

Work engagement on the other hand has been observed as an important variable that affectively and psychologically enhances work-related behaviours in a way that motivates employees to carry out their tasks willingly and actively (Catlette \& Hadden, 2001; Mokaya \& Kipyegon, 2014) and it encompasses three major features, namely: vigour, absorption, and dedication (Schaufeli \& Bakker, 2004). Therefore, owing to the ability of work engagement to improve positive work-related behaviour, the current study proposes it as a mediating variable with a view to better clarifying the association between organisational commitment and employee performance. In recent years, several studies (e.g., Hafiz, 2017; Kaplan \& Kaplan, 2018; Folorunso, Adewale \& Abodunde, 2014) have examined the direct influence of organisational commitment on employee performance. Besides, although much research has been carried out in industrial and educational settings, there appears to be a paucity of studies of this nature conducted in healthcare settings and especially in developing countries.

It follows that research is lacking on organisational commitment, work engagement and employee performance especially in the context looked at in this paper. More importantly, the need to enhance commitment levels and work engagement of nurses in the midst of the COVID-19 pandemic is highly imperative to facilitate prompt, efficient and effective service delivery. Drawing upon the aforementioned explanation, investigating how nurses' job performance can be enhanced through establishing a sense of collaboration between work 
engagement with organisational commitment is not only timely, it will possibly provide practical suggestions that can assist the healthcare industry.

\section{Literature Review and Hypotheses Development}

\subsection{Organisational Commitment}

Organisational commitment is considered to be an important element of an institution's goals and values (Gullu, Yildiz \& Kaya, 2020; Khalili \& Asmawi, 2012; Robberts, van der Poll \& Engelbrecht, 2020) since it is a source of wielding great influence on employee job performance (Adeel, Ahmad \& Waseef, 2015; Chen \& Francesco, 2003; Hafiz, 2017). It is why organisational commitment is seen as a positive evaluation of the organisation and its objectives (Adekola, 2012). Kreitner and Kinicki (2009) conceptualise organisational commitment as the level at which an individual identifies and commits him- or herself to the objectives of the workplace. Similarly, organisational commitment is viewed as a belief, acceptance and readiness to involve oneself in their workplace's goals and values by working assiduously and having a passion to maintain relationships, procedures, outcomes, etc. (Tnay, Othman, Siong, Lim \& Lim, 2013). This suggests that organisational commitment is a means of achieving both the individual and organisational values and goals through workers who are committed to them.

Similarly, Aydogan and Arslan (2020) argue that this commitment results in a sense of identification with an organisational goal, as well as the willingness to maintain relationships within the organisation. An organisation's overall effectiveness can be achieved through committed employees who are ready to work to the best of their capacity. However, organisational commitment may not be holistically captured except through the understanding of its dimensions - a three-component model of organisational commitment proposed by Meyer and Allen (1991). This view is supported by some researchers (e.g., Hafiz, 2017; Salim, Bakhit \& Noor, 2017; Tolentino, 2013). The three-component model of organisational commitment is explained in more detail below.

Affective Commitment: It is an employee's emotional bond to, identification with and involvement in the organisation. Affective commitment is an attachment that is emotional and enables a person to exhibit the same values, expectations, standards, and principles of the workplace (Beck \& Wilson, 2000). An employee who is affectively committed to his or her employer seeks to improve the operational standards and enhance overall performance. To sum up, employees with affective commitment desire to stay with their organisations because they feel strongly emotionally attached to them.

Continuance Commitment: This kind of commitment is based on cost implications analysis of leaving the organisation (Meyer \& Allen, 1991; Chuebang \& Boatham, 2011). In this case, individuals are more concerned about what they are likely to lose should they choose to resign from their jobs. These include retirement benefits, disconnection of social networks, and knowledge. This suggests that employees with continuance commitment are externally influenced to remain in the organisation for they need to.

Normative Commitment: This dimension of commitment is based on sense of moral duties to maintain employment relationships with the organisation (Meyer \& Allen, 1991; Chuebang \& Boatham, 2011). Hence, employees remain committed to the organisation because they feel it is the 'right' thing to do and their 'moral' duty as well (Martin \& Roodt, 2008). This indicates 
that employees continue to be with the organisation because they ought to. In this study, normative commitment could be viewed as a commitment that is based on moral responsibility.

\subsection{Organisational Commitment and Employee Job Performance}

Empirical evidence has shown the connection between organisational commitment and employees' job performance. For instance, Tolentino (2013) investigated the influence of organisational commitment on employee performance. Results revealed that only affective commitment significantly correlates with the job performance of academic staff, while continuance and normative commitment were found to be insignificant to the administrative personnel's job performance. In the regression analysis carried out by Hafiz (2017) on organisational commitment and employee performance in the Pakistan's banking industry, the study used 213 questionnaires to collect data from bank personnel. Statistical results indicated that organisational commitment dimensions have a positive relationship with employees' performance jointly and separately.

Similar to the work of Hafiz (2017) was the study carried out in Nigeria by Folorunso et al. (2014) who examined the effect of organisational commitment on academic staff's performance. The study utilised a questionnaire to collect data from 219 respondents. Results of their analysis revealed that organisational commitment dimensions (normative, continuance and affective) have a significant effect on academic staff performance. Elsewhere, Kaplan and Kaplan (2018) in Turkey in their work on organisational commitment and work performance demonstrated that affective commitment significantly and positively influence workplace performance, whereas normative and continuance commitment turned out to be insignificant.

In Sri Lanka, Bandula and Jayatilake (2016) carried out a study to assess whether there was a nexus between employee commitment and job performance. In their study, 115 questionnaires were administered to finance and leasing firms' employees. According to the correlation test, employee commitment was found to be positively related to the performance of employees. However, the study viewed organisational commitment as a single construct. Furthermore, in the structural model analysis undertaken by Suharto and Hendri (2019), it was established that organisational commitment predicts employee job performance.

The study by Oyeniyi, Adeyemi and Olaoye (2017) investigated the effect of organisational commitment on performance of employees in the Nigerian hospitality industry. Results of their analysis indicated positive but insignificant effect of affective and continuance commitment on job performance. Contrarily, a negative correlation was observed between normative commitment and job performance. Salim, Bakhit and Noor (2017) examined organisational commitment and work performance in Omani government departments. Their empirical findings elicited a significant impact of organisational commitment (i.e., normative, continuance and affective commitment) on work performance (i.e., both contextual and task oriented). Wadeel, Ahmad and Waseef's (2015) research in Pakistan's banking industry indicated a significant positive connection between organisational commitment and employee job performance, although organisational commitment was examined as a uni-dimensional variable. Results of a study conducted by Negin, Omid and Ahmad (2013) in Meli Bank of Iran on organisational commitment (normative, continuance and affective commitment) were found to be positively related to employees' job performance. Several more recent empirical studies (e.g., Fatoni Prihatini, \& Suryaningsih 2018; Pristiwati \& Sunuharyo, 2018; Seikh, 2017) proved that organisational commitment and employee performance were positively and significantly correlated. However, other substantial empirical studies (e.g., Adrianto \& Riyanto, 2020; Askolani \& Maulid, 2018; Pratama \& Aima, 2018) have proven that an 
insignificant association exists between organisational commitment and employee performance.

In line with these expositions, the following hypotheses are posited:

$\mathrm{H}_{1}$ : Affective commitment has a positive significant effect on employee job performance.

$\mathrm{H}_{2}$ : Continuance commitment has a positive significant effect on employee job performance.

$\mathrm{H}_{3}$ : Normative commitment has a positive significant effect on employee job performance.

\subsection{Organisational Commitment, Work Engagement and Employee Job Performance}

Work engagement is a vital concept that enhances individual and organisational performance (Knight, Patterson \& Dawson, 2017; Othman \& Mahmood, 2019). Schaufeli (2012) explained engagement as a behavioural response that physically, cognitively, emotionally and mentally attach employees to their work role. This sense of engagement is considered to be a cognitive, emotional, and behavioural state of individuals and are mostly directed towards attaining organisational objectives (Farndale \& Murrer, 2015; Shuck \& Wollard, 2010). The elements of work engagement are vigour, dedication and absorption. Vigour is the demonstration of strong energy and enthusiasm for the job (Kataria, Rastogi \& Garg, 2013). Dedication is the degree to which an employee is enthusiastic to dedicate his or her resources to the job without minding the challenges that are inherent in it (Cahill et al., 2015). Meanwhile, absorption is the inability to detach oneself from a job as a result of deep involvement in it (Jeve, Oppenheimer \& Konje, 2015).

However, many other factors have been documented in the extant literature, which may externally and internally influence employee engagement. These include: provision of good wages (Pang \& Lu, 2018), conducive work environment (Lazauskaite-Zabielske, Urbanaviciute \& Balsiene, 2018) supportive colleagues in the workplace (Yousef, 2017), selfefficacy (Mäkikangas et al., 2013; Sofiah \& Kurniawan, 2019), work-life balance (Alqarni, 2016), passion (Ho, Wong \& Lee, 2011; Burke, Astakhova \& Hang, 2015; Purba \& Ananta, 2018), high commitment level (Waqas, Mukhtar, Parveen, 2017), and free-flow communication in the work place (García-Carbonell, Martín-Alcázar \& Sanchez-Gardey, 2018).

The nexus between organisational commitment, work engagement and employee job performance can be anchored on Social Exchange Theory (SET). This theory describes how an individual assesses relationships with others or entities with a view to making decisions based on cost-benefit ratio (Ramkissoon \& Nunkoo, 2011) which may result in either positive or negative employee/organisational outcomes (Shanock \& Eisenberger, 2006). In this context, employees do evaluate the characterised benefits accrued to him/her in a certain workplace environment to determine his/her engagement level and consequently performance level. Accordingly, employees respond reciprocally to various events and circumstances in the organisations, and such reciprocal acts may include better performance.

Furthermore, the Job Demands and Resources (JD-R) model has been recognised in the extant literature as a theoretical framework that can underscore causal and resultant effects of engagement (Albrecht et al., 2018). The JD-R model proposes that there is a motivational aspect of the self (i.e., personal resources) which can spur individual and organisational outcomes, such outcomes may include, improved work engagement and performance (Knight et al., 2017). Apart from that, sense of commitment and engagement are key to the formation 
of good employee job performance (Azeem, 2010; Al Zeifeti \& Mohamad, 2017; Garg et al., 2018; Salim et al., 2017).

A substantial number of empirical researches have confirmed a positive relationship between employee engagement and organisational commitment (Cesário \& Chambel, 2017; Imam \& Shafique, 2014; Khalid \& Khalid, 2015; Rohail, Zaman, Ali, Waqas, Mukhtar, \& Parveen, 2017; Schaufeli, 2012). Conversely, work engagement has been reported by others (e.g., Alessandri Consiglio, Luthans \& Borgogni, 2018; Cesário \& Chambel, 2017; Garg \& Singh, 2019; Meyers, Kooij, Kroon, de Reuver \& van Woerkom, 2019; Rai, Ghosh, Chauhan \& Singh, 2018; Singh \& Karki, 2015) as positively influencing various types of employee performance, like job performance, in-role and extra-role performance. More so, it is noted that engaged employees make great efforts to ensure organisational goals are realised, and work beyond the designated tasks to the best of their ability (Bakker, Demerouti \& Sanz-Vergel, 2008; Christian, Garza \& Slaughter, 2011; Lockwood, 2007; Sekhar, Patwardhan \& Vyas, 2018). Research has established that personal resources (the inner self that keeps one motivated despite challenges) significantly predict work engagement, which consequently impact positively on work performance and well-being (Xanthopoulou et al., 2007; Xanthopoulou et al., 2009a; Sweetman \& Luthans, 2010).

Garg and Singh (2019) found that work engagement mediates the relationship between subjective well-being and work performance. Similarly, Putri and Setianan (2019) showed that work engagement is a suitable intervening variable in explaining the relationship between job enrichment, organisational and employees' intention to quit. All these suggest that work engagement is a potential underlying mechanism through which organisational commitment (i.e., normative, continuance and affective commitment) can influence employees' performance. Based on what the aforementioned argument reported here, the following hypotheses are suggested:

$\mathrm{H}_{4}$ : Work engagement mediates the relationship between affective commitment and employee job performance.

$\mathrm{H}_{5}$ : Work engagement mediates the relationship between continuance commitment and employee job performance.

$\mathrm{H}_{6}$ : Work engagement mediates the relationship between normative commitment and employee job performance.

Consequently, we arrive at

Figure 1 which illustrates how these work in the model.

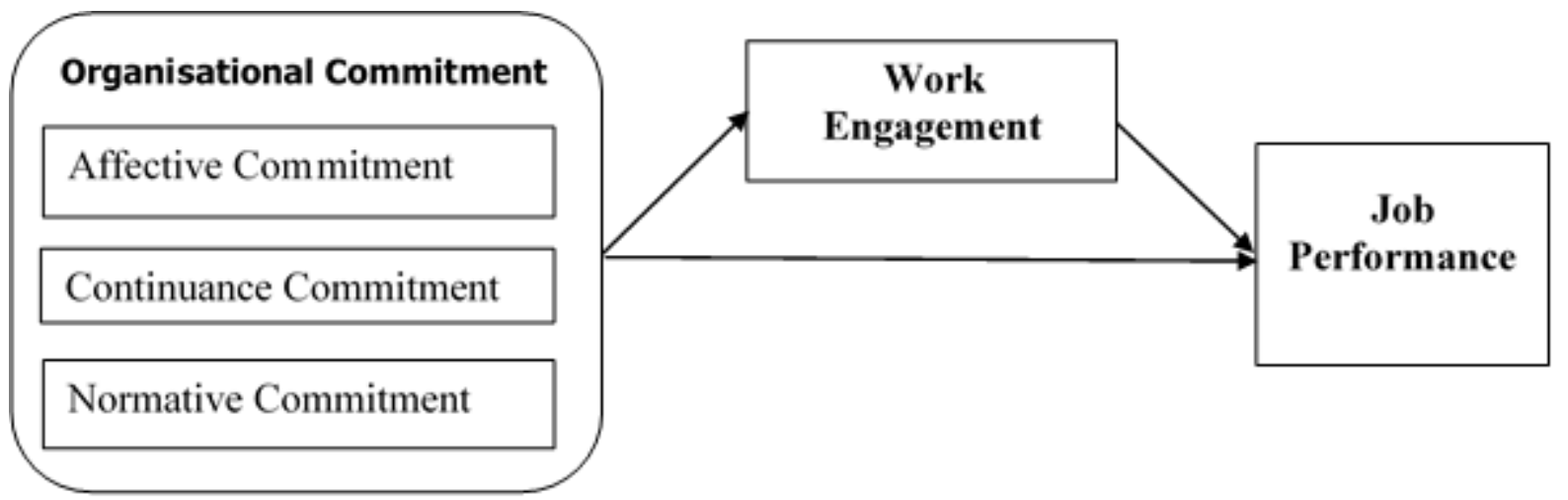


Figure 1: Model devised for the study

\section{Research Methodology}

\subsection{Data Collection}

The design for the study is cross-sectional since the data was collected at one point in time from respondents. The targeted population of the study comprised 4,680 qualified nurses working in public hospitals located in Kaduna State, Nigeria. In line with Krejcie and Morgan's (1970) recommendation, a minimum sample size of 354 is enough for a population of 4,680. Besides, Israel (2013) suggested that $30 \%$ of the minimum sample size can be added to take care of some errors such as improper completion of questionnaires, void questionnaires and failure of some respondents to return the questionnaires. Having added $30 \%$ of the minimum sample size, a 406-sample size was obtained. Subsequently, 406 questionnaires were administered to the registered nurses working in the public hospitals in Kaduna State in May 2020, using the simple random sampling method. This is to ensure that nurses in the survey exercise were duly represented.

\subsection{Instrument and Measurement}

The instrument (questionnaire survey) designed for the data collection contains two main sections. Section A deals with the questions related to demographic profile of respondents such as gender, age, education qualifications, and employment, while section B consists of questions regarding organisational commitment (i.e., normative, continuance and affective commitment), work engagement, and job performance (see the Appendix). In measuring organisational commitment, 18 items were adapted from Meyer and Allen's (1991) scale, six items for each of the dimensions (i.e., normative, continuance and affective commitment) while work engagement was measured using six items adapted from Schaufeli and Bakker (2004). Finally, job performance was measured from the scale developed by William and Anderson (1991) with four items. All 28 items were anchored on a five-point Likert scale ranging from 1 to 5 which respectively indicate strongly disagree to strongly agree.

\subsection{Tools and Model Estimation}

This study employed the Partial Least Squares-Structural Equation Model (PLS-SEM) to carry out data analysis. Accordingly, measurement and structural model approaches (i.e., a two-stage approach) were utilised recommended by Hair, Ringle, and Sarstedt (2011) in Smart PLS 3 to obtain valid and reliable results.

\section{Data Analysis}

\subsection{Response Rate}

Table 1 indicates that 361 questionnaires representing $89 \%$ served for the analysis. Specifically, a minimum response rate of $30 \%$ is considered sufficient for research of this nature (see Sekaran, 2003).

Table 1: Response Rate Analysis

\begin{tabular}{lc}
\hline Response & Frequency/Rate \\
\hline No. of distributed questionnaires & 406 \\
No. of returned of questionnaires & 378 \\
No of returned and usable questionnaires & 361
\end{tabular}




\subsection{Demographic Profile of the Respondents}

Table 2 illustrates the descriptive statistics of respondents. The age distribution of the respondents demonstrates that $7.5 \%$ are in the 18 to 25 age range, $16.6 \%$ in the 26 to 30 age range, $45.3 \%$ between 31 to 35 years of age, $19.9 \%$ in the 36 to 40 age range, while $10.8 \%$ respondents are above 40 . Also, male respondents account for $59.8 \%$ of the total responses while females represent $40.2 \%$ of the sample. Moreover, $23.8 \%$ of the respondents have a diploma in general nursing, $49.3 \%$ possess a B.Sc. in Nursing Science, $19.9 \%$ have a postgraduate certificate in Nursing Science and others account for $7 \%$ of the total responses. Finally, 59.7\% of respondents have worked at their current hospitals for between 0 to 5 years, $28.4 \%$ of respondents did so between 6 and 10 years, $7.4 \%$ have worked for between 11 and 15 years, while $4.6 \%$ have worked for more than 5 years.

Table 2: Demographic Profile of the Respondents

\begin{tabular}{|c|c|c|c|c|}
\hline \multicolumn{2}{|c|}{ Demographic Profile } & Frequency & Percentage & $\begin{array}{l}\text { Cumulative } \\
\text { Percentage }\end{array}$ \\
\hline \multirow{5}{*}{$\ddot{4}$} & $18-25$ & 27 & 7.5 & 7.5 \\
\hline & $26-30$ & 60 & 16.6 & 24 \\
\hline & $31-35$ & 163 & 45.3 & 69.3 \\
\hline & $36-40$ & 72 & 19.9 & 89.2 \\
\hline & Above 40 & 39 & 10.8 & 100 \\
\hline \multirow{2}{*}{ 离 } & Female & 216 & 59.8 & 59.8 \\
\hline & Male & 145 & 40.2 & 100 \\
\hline \multirow{4}{*}{ : } & Diploma & 86 & 23.8 & 23.8 \\
\hline & B.Sc. & 178 & 49.3 & 73.1 \\
\hline & Postgraduate & 72 & 19.9 & 93 \\
\hline & Others & 25 & 7 & 100 \\
\hline \multirow{4}{*}{ 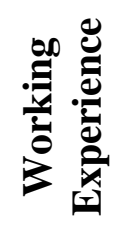 } & $0-5$ & 248 & 59.7 & 59.7 \\
\hline & $6-10$ & 135 & 28.4 & 88 \\
\hline & $11-15$ & 35 & 7.4 & 95.4 \\
\hline & Above 15 & 22 & 4.6 & 100 \\
\hline
\end{tabular}

\subsection{Measurement Model}

A measurement model explains how each construct is measured and this was achieved through the assessment of indicator reliability, internal consistency, and convergent validity (Hair, Hult, Ringle \& Sarstedt, 2017). Figure 2 is a measurement model showing the indicators' loading for this study. 


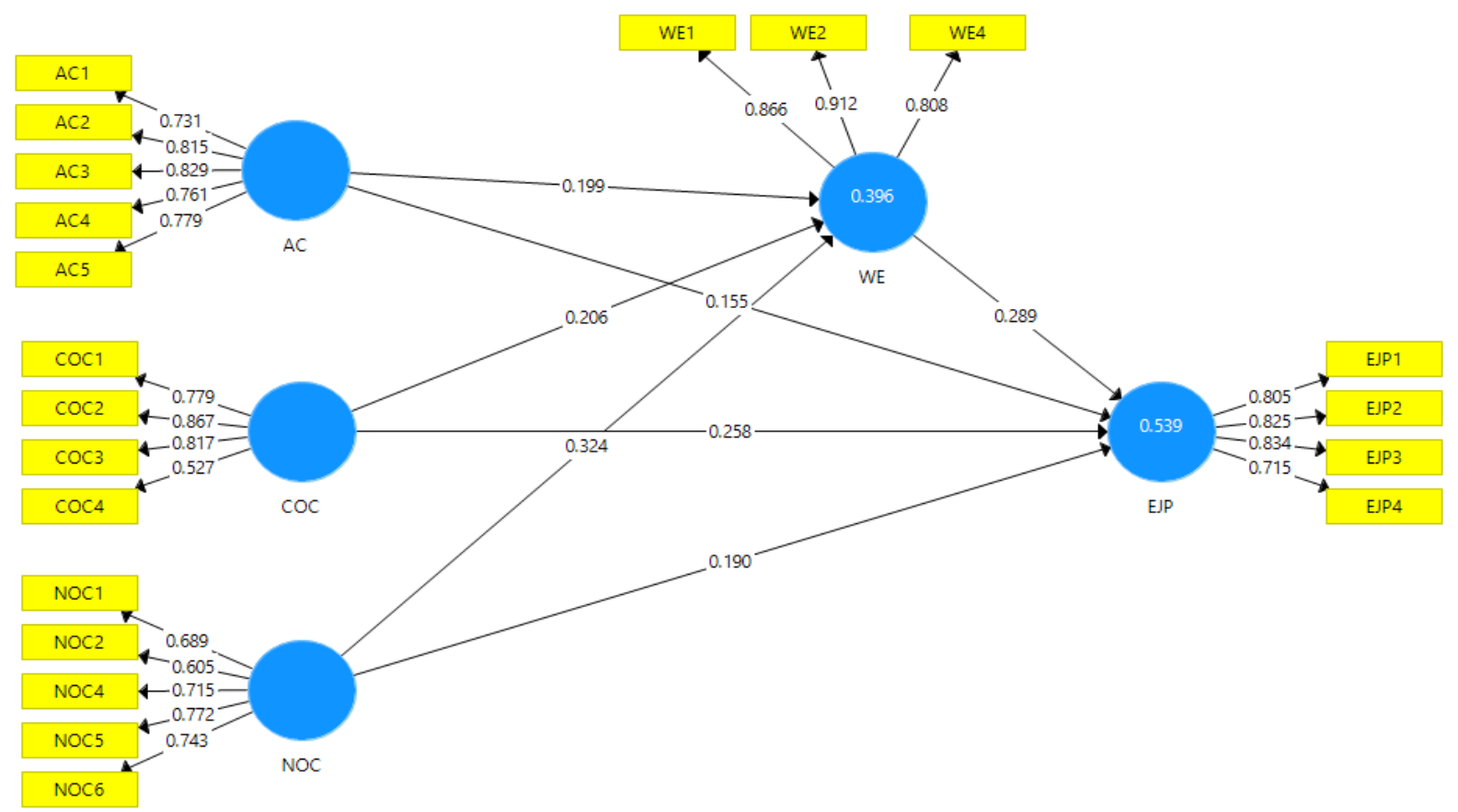

Figure 2: Measurement Model

Figure 2 and Table 3 summarise the indicator reliability of each item measuring constructs chosen for this study. Indicator reliability explains the fittingness and reliability of each item loading in measuring a certain construct for a given research study (Hair, Black, Babin \& Anderson, 2010). Indicator reliability is satisfied when each item value loads above 0.5 (Sekeran, 2010). Based on the values that are reported in Table 3 and Figure 2, individual indicator reliability has been satisfactorily attained as items loading values range from 0.527 to 0.912 . However, it should be noted that one out of six items (i.e., AC6) was deleted from affective commitment items, two out of six items (i.e., COC5 \& COC6) were deleted from continuance commitment and three out of six items (i.e., WE3, WE5 \& WE6) were deleted from work engagement. This is because those items did not meet the minimum required value of 0.5 and their deletion brought about a significant improvement in CR values (see Hair, Black, Babin \& Anderson, 2014).

Table 3: Indicator Reliability, Internal Consistency, and Convergent Validity

\begin{tabular}{llllll}
\hline Construct & Items & Loadings & AVE & CR & CA \\
\hline Job Performance & EJP1 & 0.805 & 0.634 & 0.873 & 0.806 \\
& EJP2 & 0.825 & & & \\
& EJP3 & 0.834 & & & \\
& EJP4 & 0.715 & & & 0.843 \\
Affective & AC1 & 0.731 & 0.614 & 0.888 & \\
Commitment & AC2 & 0.815 & & & \\
& AC3 & 0.829 & & & \\
& AC4 & 0.761 & & & \\
Continuance & AC5 & 0.779 & & 0.744 \\
Commitment & COC1 & 0.779 & 0.576 & & \\
& COC2 & 0.869 & & & \\
& COC3 & 0.817 & & & \\
\hline
\end{tabular}




\begin{tabular}{llllll}
\hline Construct & Items & Loadings & AVE & CR & CA \\
\hline Normative & NORC1 & 0.689 & 0.500 & 0.833 & 0.763 \\
Commitment & NORC2 & 0.605 & & & \\
& NORC3 & 0.715 & & & \\
& NORC4 & 0.772 & & & \\
& NORC5 & 0.743 & & & 0.828 \\
\hline Work Engagement & WE1 & 0.866 & 0.746 & 0.898 & \\
& WE2 & 0.912 & & & \\
& WE4 & 0.808 & & & \\
\hline
\end{tabular}

Note: AVE represents Average Variance Extracted; CR represents Composite Reliability; CA represents Cronbach's Alpha

Also, Table 3 symbolises the internal consistency reliability of each construct (construct reliability). It evaluates whether similarities exist in an item measuring a construct with regard to their scores, that is, how high correlations between items are (Hair et al., 2017). In quantitative research, CA and CR are normally used to check for internal consistency reliability of a study. According to Hair et al. (2017), both CA and CR values are expected to be 0.7 or above. Referring to this study, both CA and CR are correspondingly above the minimum threshold values of 0.7 . Hence, consistency reliability has been satisfactorily confirmed. More so, convergent validity is the degree to which a measure is positively correlated to other measures of the same construct and can be established by assessing the AVE value. AVE is the grand mean value of the squared loadings of the indicators with respect to the construct, that is, the sum of the squared loadings divided by the number of indicators (Hair et al., 2017). Its value is placed at 0.5 or above (Hair et al., 2011). Referring to the AVE values shown in Table 3 convergent validity of each study's construct has been confirmed.

Table 4: Discriminant Validity using the Fornell-Larcker Criterion

\begin{tabular}{llllll}
\hline & AC & COC & EJP & NOC & WE \\
\hline AC & $\mathbf{0 . 7 8 4}$ & & & & \\
COC & 0.612 & $\mathbf{0 . 7 5 9}$ & & & \\
EJP & 0.582 & 0.613 & $\mathbf{0 . 7 9 6}$ & & \\
NOC & 0.619 & 0.584 & 0.601 & $\mathbf{0 . 7 0 7}$ & \\
WE & 0.526 & 0 & 0.612 & 0.568 & $\mathbf{0 . 8 6 3}$ \\
\hline
\end{tabular}

Note: AC means Affective Commitment; COC means Continuance Commitment; EJP means Employee Job Performance; NOC means Normative Commitment; WE means Work Engagement; The bold face stand for the square root of AVE of each latent variable.

Discriminant validity was also evaluated to ascertain the constructs' validity. It is the degree to which a construct tends to vary from other sets of constructs by empirical standards. Table 4 above depicts the discriminant validity of the latent variables and the square root of AVE of each variable is expected to be greater than its correlations with any other construct. In line with the results of discriminant validity in this study, the square root of the AVE is higher than its correlation with other latent variables (see Garson, 2016). In Table 4, the numbers in bold face denote the square root of AVE of each latent variable. As shown, the diagonal value (in bold) is above the value in its row and column. Consequently, discriminant validity for each of the constructs in this study has been accomplished.

\subsection{Hypotheses Testing (Structural Model)}

Having established the fitness of the measurement model, the next step is to confirm the structural model. The structural model was assessed through bootstrapping analysis to establish 
two things: firstly, the results for the direct effect of organisational commitment and employee job performance; and secondly, the mediating effect of work engagement on the direct relationship.

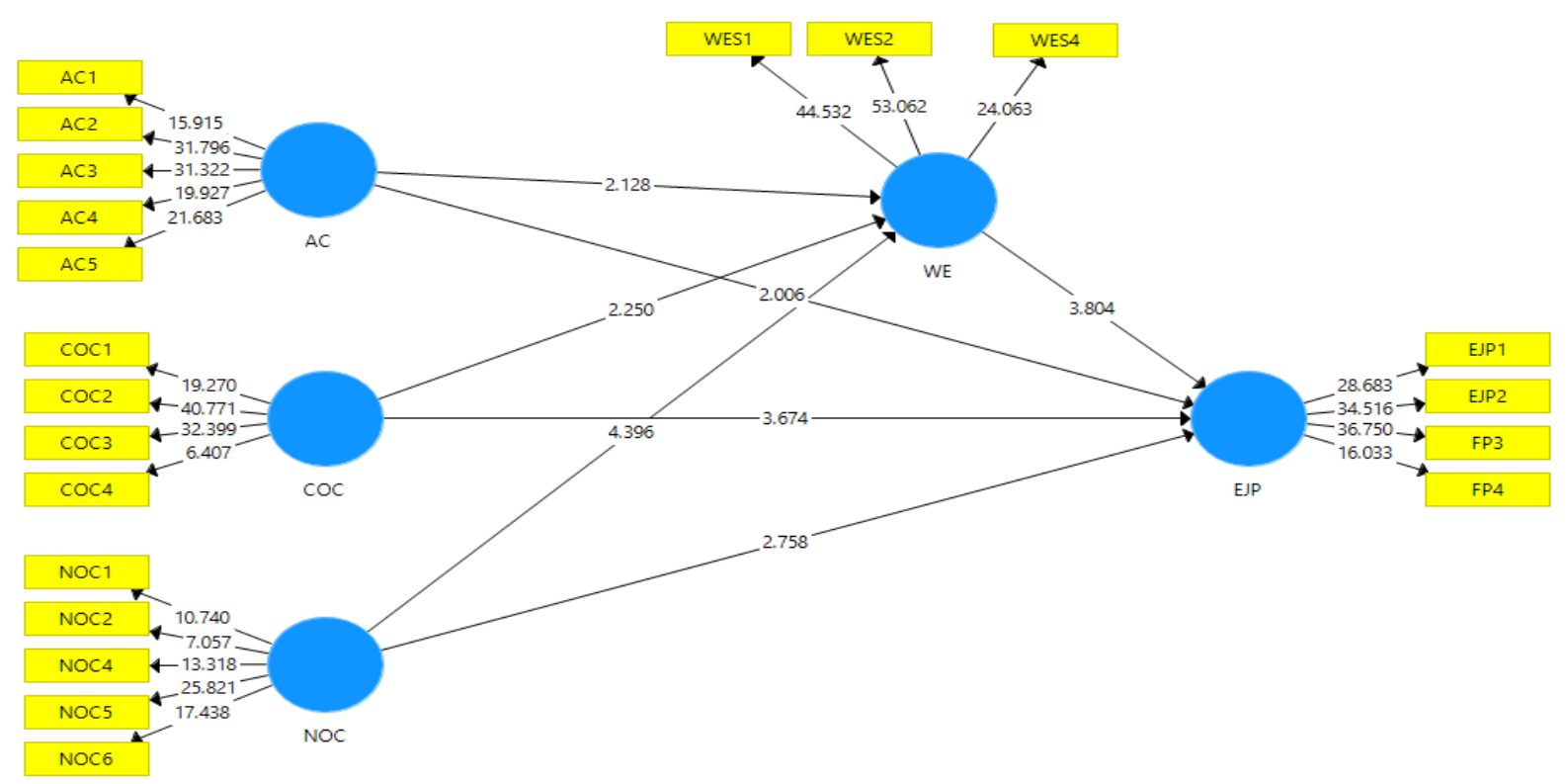

Figure 3: Structural Model

Figure 3 and Table 5 demonstrate the results of the structural model through bootstrapping. Table 5 represents the results of the hypotheses formulated earlier. As shown in Table 5 it is observed that affective commitment has a positive significant effect on nurses' job performance ( $\beta=0.293, t=4.460, p<0.01)$. This means, if the level of affective commitment rises by one unit, nurses' job performance will improve by $29.3 \%$. Also, BCI $=0.177$ and 0.437 which do not include zero, so this is a confirmation of the significant effect of affective commitment on nurses' job performance. Therefore, $\mathrm{H}_{1}$ which states that affective commitment has a significant positive effect on nurses' job performance is empirically supported.

Table 5: Hypotheses Testing

\begin{tabular}{lccccccc}
\hline & Beta & STDEV & T Stat & P Values & \multicolumn{2}{c}{ BCI } & Decision \\
& & & & & $2.5 \%$ & $97.5 \%$ & \\
\hline AC ->EJP & 0.293 & 0.066 & 4.460 & 0.000 & 0.177 & 0.437 & Supported \\
COC ->EJP & 0.001 & 0.041 & 0.030 & 0.976 & -0.086 & 0.078 & NS \\
NOC->EJP & 0.170 & 0.066 & 2.567 & 0.011 & 0.031 & 0.293 & Supported \\
AC->WE $>$ EJP & 0.342 & 0.033 & 5.425 & 0.000 & 0.067 & 0.151 & Supported \\
COC $>$ WE $>$ EJP & 0.005 & 0.046 & 0.453 & 0.791 & -0.069 & 0.053 & NS \\
NOC $>$ WE $>$ EJP & 0.114 & 0.040 & 2.834 & 0.004 & 0.183 & 0.472 & Supported \\
\hline
\end{tabular}

Note: AC means Affective Commitment; COC means Continuance Commitment; EJP means Employee Job Performance; NOC means Normative Commitment; WE means Work Engagement; BCI means Bias Confidence Interval; NS means Not Supported

However, continuance commitment fails to reveal a positive significant effect on nurses' job performance $(\beta=0.001, t=0.030, p>0.1)$ since the outcome obtained is not statistically significant enough to support the hypothesised relationship. Confirming the non-significant effect of continuance commitment on nurses' job performance is also the outcome $(\mathrm{BCI}=0.086$ $\& 0.078$ ) as it includes zero. Thus, $\mathrm{H}_{2}$ which states that continuance commitment has a positive significant effect on nurses' job performance is not supported. Furthermore, normative 
commitment was found to exert a positive significant effect on nurses' job performance $(\beta=$ $0.170, t=2.567, p>0.1)$. Also, $\mathrm{BCI}=0.031$ and 0.293 which do not include zero does confirm the significant effect of normative commitment on nurses' job performance. By implication, as the level of normative commitment increases by one unit, nurses' job performance also improves by $17 \%$. Thus, $\mathrm{H}_{3}$ which states that normative commitment has a significant positive effect on nurses' job performance is supported empirically based on the result obtained. Also, the coefficient of determination $\left(\mathrm{R}^{2}\right)$ for the direct relationship indicates 0.539 , which means $53.9 \%$ variance in nurses' job performance is accounted for by normative commitment, continuance commitment and affective commitment. The coefficient of this study according to Chin (1998) is termed as moderate.

Based on Preacher and Hayes' (2008) mediation analysis procedure, the mediation results ( $\beta=$ $0.342 ; \mathrm{t}=5.425, \mathrm{p}<0.01)$ also confirm that work engagement significantly mediates the relationship between affective commitment and nurses' job performance. Furthermore, since the corresponding BCI values (i.e., $0.067 \& 0.151$ ) of the mediation relationship do not include zero, the mediation is demonstrated. Thus, $\mathrm{H}_{4}$ which reveals that work engagement mediates the relationship between affective commitment and nurses' job performance was also supported. However, the results $(\beta=0.005 ; \mathrm{t}=0.453, \mathrm{p}>0.1)$ of the mediating relationship between continuance commitment and nurses' job performance was insignificant. Therefore, $\mathrm{H}_{5}$ was not supported based on the documented findings. Moreover, the results $(\beta=0.342 ; \mathrm{t}=$ $5.425, \mathrm{p}<0.05)$ demonstrate that work engagement significantly mediates the relationship between normative commitment and nurses' job performance. Besides, the non-inclusiveness of zero in its corresponding BCI values (i.e. $0.183 \& 0.472$ ) also affirms the significance of the mediating relationship between normative commitment and nurses' job performance. Thus, $\mathrm{H}_{6}$ which asserts that work engagement mediates the relationship between normative commitment and nurses' job performance was also supported. Regarding the coefficient of determination $\left(\mathrm{R}^{2}\right)$ for the mediating relationship, the $\mathrm{R}^{2}$ value of 0.396 denotes that normative, continuance and affective commitment explain $39.6 \%$ of the variance in the mediating variable (work engagement).

Table 6: Effect Size of Exogenous Variables on Endogenous Variables

\begin{tabular}{lll}
\hline Construct & $f^{2}($ EJP $)$ & Effect Size \\
\hline WE & 0.110 & Moderate \\
AC & 0.077 & Small \\
COC & 0.026 & Small \\
NOC & 0.039 & Small \\
\hline
\end{tabular}

Referring to the results obtained in Table 6, it reveals that nurses' job performance is explained by work engagement, normative, continuance and affective commitment by showing effect sizes of $0.0110,0.077,0.026$, and 0.039 , respectively. Based on the suggestion made by Cohen (1988) and Hair et al. (2013), threshold values of 0.02, 0.15, and 0.35 are normally used to describe small, medium, and large effect size $\left(\mathrm{f}^{2}\right)$, respectively. In this case, normative, continuance and affective commitments have a small effect size while work engagement has a large effect size on the endogenous variable (job performance).

Table 7: Predictive Relevance of Exogenous Variables

\begin{tabular}{llll}
\hline Construct & SSO & SSE & $\mathrm{Q}^{2}=1-\mathrm{SSE} / \mathrm{SSO}$ \\
\hline Job Performance & $1,308.000$ & 981.878 & 0.249 \\
\hline
\end{tabular}

Note: SSO (sum of squared observations); SSE (sum of squared prediction errors) 
Table 7 signifies the blindfolding result of the cross-validated redundancy $\left(Q^{2}\right)$ of the reflective endogenous latent variable of this model. As shown in the table, the cross-validated redundancy $\left(Q^{2}\right)$ is greater than zero. Therefore, it evidently shows there is a path model predictive relevance (Chin, 1998; Hair et al., 2014; Hayes, 2009).

\section{Discussion and Conclusion}

In this study, affective commitment and normative commitment have a positive significant effect on nurses' job performance in public hospitals in the state of Kaduna, Nigeria. In a broader sense, when affective commitment (emotional attachment) of nurses to their organisation is high, they tend to function better. Also, nurses' job performance was observed to improve owing to normative commitment (i.e., commitment that is based on moral duties). Nevertheless, continuance commitment fails to show a significant effect on nurses' job performance. The possible reason for the insignificant effect of continuance commitment on nurses' job performance in the context of this study might be due to the conditional nature of the commitment. Therefore, it is a kind of commitment resulting from the fear of the unknown or possible loss of benefits offered by the organisation. As such, the major predictors of nurses' job performance in findings are affective and normative commitment. These results are similar to what has been reported by Folorunso, Adewale and Abodunde (2014), Hafiz (2017), Kaplan and Kaplan (2018), and Negin, Omid, and Ahmad (2013).

The results also emphasise the mediating effect of work engagement in expounding the relationship between normative, continuance and affective commitment and nurses' job performance. In line with these findings, it was observed that employees whose commitment is based on emotional attachment (affective commitment) and moral duties (normative commitment) display a high sense of engagement with their job, feel more dedicated to it and in turn perform better and beyond the call of duty. Specifically, it is revealed that work engagement is a significant factor that needs to be considered to boost commitment level of nurses and consequently their job performance. The mediating results of this study share some similarities with the results of Garg and Singh (2019), Putri and Setianan (2019) and Sekhar, Patwardhan and Vyas (2018) where work engagement was found to be relevant in terms of enhancing performance. Thus, it can be concluded that work engagement is an important underlying mechanism that expounds the relationship between organisational commitment and nurses' job performance.

\section{Theoretical Implications}

Several previous empirical studies have underscored the importance of organisational commitment and work engagement in enhancing positive organisational outcomes (e.g., job performance) but very few or no studies have clarified how organisational commitment dimensions influence employees' job performance. This study, therefore, aimed to explain the underlying mechanism through which organisational commitment influences job performance of nurses in Nigeria. The theoretical contributions of this study emanate from an indirect explanation of organisational commitment and nurses' job performance-relationship by employing the three-component model of Meyer and Allen (1991) who investigated organisational commitment.

\section{Practical Implications}

For practical purposes it is recommended that public healthcare managers and policymakers in Nigeria and other stakeholders increase nurses' level of organisational commitment and work 
engagement by improving their well-being, ensuring career growth opportunities exist, devising maximum care, providing uninterrupted support systems, including adequate rewards and compensation systems. Furthermore, compensation, allowances, bonuses and other fringe benefits should be reviewed upward as these will go a long way in boosting nurses' level of commitment to their organisations and make them feel more engaged which, in turn, would enhance how well they do their job. The overall recommendations of this study should be implemented in the healthcare sector since it has considerable influence on nurses' job performance and has meaningful implications for healthcare service delivery.

\section{Limitations of Study and Suggestions for Future Research}

This study utilised a cross-sectional research approach and therefore may not make it possible to draw causal inferences from the studied population (Sekaran \& Bougie, 2010). With this in mind, future studies may employ the longitudinal research approach instead of the cross-sectional one to collect data. The present study has established empirically the underlying process through which work engagement contributes to the nexus of organisational commitment and the employee job performance. Finally, research of this nature could be replicated in other sectors besides healthcare as this would further validate any generalisation of this study's findings.

\section{References}

Adeel, A., Ahmad, B., \& Waseef, H. (2015). The impact of organizational commitment on job satisfaction and job performance: an empirical study from Pakistan, IOSR Journal of Business and Management, 17(6), 75-80.

Adekola, B. (2012). The Impact of Organizational Commitment on job satisfaction: A study of employee at Nigerian Universities. International Journal of Human Resources Studies, 2(2), 20-29.

Adrianto \& Riyanto, S. (2020). The effect of organizational commitment, employee engagement, and organizational citizenship behavior on employee performance at pt. titan infra energy - head office. IOSR Journal of Humanities and Social Science, 25(1) 22 - 31. doi: 10.9790/0837- 2501092231

Al Zeifiti, S. M., \& Mohamad, N. A. (2017). The Influence of Organizational Commitment on Omani Public Employees' Work Performance. International Review of Management and Marketing, 7(2), 151-160.

Albrecht, S. L., Bakker, A. B., Gruman, J. A., Macey, W. H. \& Saks, A. M. (2015). Employee engagement, human resource management practices and competitive advantage: an integrated approach. Journal of Organizational Effectiveness: People and Performance, 2(1), 7-35.

Alessandri, G., Consiglio, C., Luthans, F., \& Borgogni, L. (2018). Testing a dynamic model of the impact of psychological capital on work engagement and job performance. Career Development International, 23(1), 33-47.

Alqarni, S. A. Y. (2016). Quality of work life as a predictor of work engagement among the teaching. International Journal of Humanities and Social Science, 6(8), 118 - 135.

Askolani, A., \& Maulid, D. L. (2018). The effect of job satisfaction and organizational commitment to performance of employees Dinas Pendidikan Kota Bandung. 1st International Conference on Economics, Business, Entrepreneurship, and Finance. doi: https://doi.org/10.2991/icebef-18.2019.60.

Aydoğan, E. and Arslan, Ö. (2020). HRM practices and organizational commitment link: maritime scope. International Journal of Organizational Analysis, 12(2), 123129. https://doi.org/10.1108/IJOA-02-2020-2038 
Azeem, S. M. (2010). Job satisfaction and organizational commitment among employees in the Sultanate of Oman. Psychology, 1(04), 295.

Bakker, A. B., Demerouti, E., \& Sanz-Vergel, A. I. (2014). Burnout and work engagement: The JD-R approach. Annual Review of Organizational Psychology and Organizational Behavior, 1, 389-411.

Bandula, P.M.K.U., \& Jayatilake, L.V.K. (2016). Impact of employee commitment on job performance: based on leasing companies in Sri Lanka. International Journal of Arts and Commerce, 5(8), 8-22.

Burke, R. J., Astakhova, M. N., \& Hang, H. (2015). Work passion through the lens of culture: harmonious work passion, obsessive work passion, and work Outcomes in Russia and China. Journal of Business and Psychology, 30(3), 457 - 471. https://doi.org/10.1007/s10869-017- 9500-2

Cahill, K. E., McNamara, T. K., Pitt-Catsouphes, M., \& Valcour, M. (2015). Linking shifts in the national economy with changes in job satisfaction, employee engagement, and work life balance. Journal of Behavioral and Experimental Economics, 56, 40-54.

Catlette, B., \& Hadden, R. (2001). Contented cows give better milk: the plain truth about employee relations and your bottom line. Germantown: Saltillo Publishing.

Cesário, F., \& Chambel, M. (2017). Linking organizational commitment and work engagement to employee performance. The Journal of Corporate Management, 24(2), 152-158.

Chen, Z. X., \& Francesco, A. M. (2003). The Relationship between the three components of commitment and employee performance in China. Journal of Vocational Behavior, 62, 490-510.

Christian, M. S., Garza, A. S., and Slaughter, J. E. (2011). Work engagement: A quantitative review and test of its relations with task and contextual performance. Personnel Psychology, 64, 89-136.

Chuebang, P., \& Boatham, S. (2011). Voluntary turnover intentions: Effects on perceived organizational support and organizational commitment of Thai employees of Rajabhat universities. Review of Business Research, 11(3), 51-63.

Farndale, E., \& Murrer, I. (2015). Job resources and employee engagement: a cross- national study. Journal of Managerial Psychology, 30, 610-626. doi:10.1108/jmp-09-2013-0318

Fatoni, M., Prihatini, D., \& Suryaningsih, I. B. (2018). The role of OCB in mediating the effect of employee engagement and organizational commitment on employee performance: contract vs permanent employees. International Journal of Scientific Research and Management, 2(4), 56-60.

Folorunso, O.O., Adewale, A.J., \& Abodunde, F.M. (2014). Exploring the effect of organizational commitment dimensions on employees' performance: An empirical evidence from academic staff of Oyo State owned tertiary institutions, Nigeria, International Journal of Academic Research in Business and Social Sciences, 4(8), 275286.

García-Carbonell, N., Martín-Alcázar, F., \& Sanchez-Gardey, G. (2018). Determinants of building consistent human resources management systems: A focus on internal communication. International Journal of Manpower, 39(3), 354-377. https://doi.org/10.1108/ IJM-06-2016-0140

Garg, K., Dar, I. A. \& Mishra, M. (2018). Job satisfaction and work engagement: a study using private sector bank managers. Advances in Developing Human Resources, 20(1), 58-71. tps://doi.org/10.1177/15234223177429 87

Garg, N., \& Singh, P. (2019). Work engagement as a mediator between subjective well-being and work-and-health outcomes, Management Research Review, 43(6), 735-752. doi: 10.1108/MRR-03-2019-014

Garson, D. (2016). Partial Least Squares: Regression \& Structural Equation Models. USA: 
Statistical Associates Publishing.

Gibson, E.B. (2012). Introduction to job satisfaction and employees' performance in the West Indies. Human Resource Management Review, 2, 10.

Gile, P. P., Samardzic, M. B., \& Klundert, J. P. D. (2018). The effect of human resource management on performance in hospitals in Sub-Saharan Africa: a systematic literature review. Human Resources for Health, 16, 34.

Gullu, Yildiz, Kaya, R. (2020). The mediating effect of organizational commitment between mobbing and turnover intention: an application on physical education and sports teachers. European Journal of Educational Studies, 7(2), 181-190. doi: 10.5281/zenodo.3726362

Hafiz, A. Z. (2017). Relationship between Organizational Commitment and Employee's Performance Evidence from Banking Sector of Lahore. Arabian Journal of Business and Management Review, 7(2), 304.

Hair, J. F., Ringle, C. M., \& Sarstedt, M. (2013). Partial least squares structural equation modeling: rigorous applications, better results and higher acceptance. Long Range Planning, 46(1-2), 1-12.

Hanaysha, J. (2016). Testing the effects of employee engagement, work environment, and organizational learning on organizational commitment. Procedia - Social and Behavioral Sciences, 229, 289-297.

Ho, V., Wong, S., \& Lee, C. H. (2011). A tale of passion: linking job passion and cognitive engagement to employee work performance. Management Faculty Publications, 48, 1 41.

Hsu, P.Y. (2005). The research of the influence of cross-cultural on the job performance: The Case on Philippine \& Thailand Labor in High-Tech Industry. Unpublished Master's Thesis, National Cheng Kung University, Taiwan.

Imam, A., \& Shafique, M. (2014). Impact of employee engagement in retaining employees through mediating effect of job satisfaction and organizational commitment and moderating effect of job stress: A Corporate banking sector study of Pakistan. Journal of Applied Environmental and Biological Sciences, 4(12), 1-15.

Ismail, H. N., Iqbal, A., \& Nasr, L. (2018). Employee engagement and job performance in Lebanon: the mediating role of creativity. International Journal of Productivity and Performance Management, 68(3), 506-523. doi:https://doi.org/10.1108/IJPPM-022018-0052

Jang, J., \& Kandampully, J. (2018). Reducing employee turnover intention through servant leadership in the restaurant context: A mediation study of affective organizational commitment. International Journal of Hospitality \& Tourism Administration, 19(2), 125- 141. https://doi.org/10.1080/15256480.2017.1305310

Jeve, Y. B., Oppenheimer, C., \& Konje, J. (2015). Employee engagement within NHS: A crosssectional study. International Journal of Health Policy and Management, 4(2), 85-90.

Kaplan, M., \& Kaplan, A. (2018). The Relationship between organizational commitment and Work Performance: A Case of Industrial Enterprises. Journal of Economic and Social Development, 5(1), 46-50.

Kataria, A., Rastogi, R., \& Garg, P. (2013). Organizational effectiveness as a function of employee engagement. South Asian Journal of Management, 20(4), 56-73.

Khalid, A., \& Khalid, S. (2015). Relationship between organizational commitments, employee engagement and career satisfaction a case of university of Gujrat, Pakistan. Journal of South Asian Studies, 3(3), 323-330

Khalili, A., \& Asmawi, A. (2012). Appraising the impact of gender differences on organizational commitment: Empirical evidence from a private SME in Iran. International Journal of Business and Management, 7(5), 100-110. 
Knight, C., Patterson, M., \& Dawson, J. (2017). Building work engagement: a systematic review and meta-analysis investigating the effectiveness of work engagement interventions. Journal of Organizational Behaviour, 38(6), 792-812.

Kreitner, R., \& Kinicki, A. (2006). Organizational behaviour, 9th ed. New York: McGraw Hill Irwin.

Krejcie, R. V., \& Morgan, D. W. (1970). Determining sample for research activities. Educational and Psychological Measurement, 38, 607-610.

Kuye, O. L., Akinwale, O. E. (2020). Conundrum of bureaucratic processes and healthcare service delivery in government hospitals in Nigeria. Journal of Humanities and Applied Social Sciences. https://doi.org/10.1108/JHASS-12-2019-0081

Lazauskaite-Zabielske, J., Urbanaviciute, I. \& Balsiene, R, R. (2018). From psychosocial working environment to good performance: the role of work engagement. Baltic Journal of Management, 13(1), https://doi.org/10.1108/BJM-10-2017- 0317

Lockwood, N. R. (2007). Leveraging employee engagement for competitive advantage. Society for Human Resource Management Research Quarterly, 1, 1-12.

Mäkikangas, A., Feldt, T., Kinnunen, U. \& Mauno, S. (2013). Does personality matter? A review on individual differences in occupational well-being. In Bakker, A.B. (Ed.), Advances in Positive Organizational Psychology (pp. 107-143). Bingley: Emerald.

Maleka, M., Mpofu, M., Hlatywayo, C. K., Meyer, I., Carr, S., \& Parker, J. (2019). Employee engagement, organisational commitment, and job satisfaction in Namibia, South Africa, and Zimbabwe: An exploratory study. Journal of Psychology in Africa, 29, 4. doi.org/10.1080/14330237.2019.1647964

Martin, A., \& Roodt, G. (2008). Perceptions of organizational commitment, job satisfaction and turnover intentions in a post-merger South African tertiary institution. South African Journal of Industrial Psychology, 43(1), 23-31.

Mathis, R.L., \& Jackson, J.H. (2009). Human Resource Management. Mason, Ohio: South Western Cengage Learning.

Meyer, J.P., \& Allen, N.J. (1991). A three-component conceptualization of organizational commitment. Human Resource Management Review, 1, 61-89.

Meyer, J.P., \& Herscovitch, L. (2001). Commitment in the workplace toward a general model. Human Resource Management Review, 11, 299-326.

Meyer, J.P., Becker, T.E., \& Vandenberghe, C. (2004). Employee commitment and motivation: A conceptual analysis and integrative model. Journal of Applied Psychology, 89(6), 9911007.

Meyers, C., Kooij, D., Kroon, B., de Reuver, R., \& van Woerkom, M. (2019). Organizational support for strengths use, work engagement, and extra-role performance: the moderating role of age. Journal of Applied Research in Quality of Life, 15(2). doi: 10.1007/s11482018-9702-4

Mokaya, S. O., \& Kipyegon, M. J. (2014). Determinants of Employee Engagement in the Banking Industry in Kenya: Case of Cooperative Bank. Journal of Human Resources, 2(2), 187-200.

Negin M., Omid M., \& Ahmad B.M. (2013). The impact of organizational commitment on employees job performance. "A study of Meli Bank". International Journal of Contemporary Research in Business, 5, 164-171.

Ngwenya, B. \& Pelser, T. (2020). Impact of psychological capital on employee engagement, job satisfaction and employee performance in the manufacturing sector in Zimbabwe. SA Journal of Industrial Psychology, 46(0), 1 - 12.

Nmadu, G. (2013). Employees performance and its effects on their job performance in workplace. Kuwait Chapter of Arabian Journal of Business and Management Review, 5 , 11. 
Othman, S. A. \& Mahmood, N. H. N. (2019). Linking employee engagement towards individual work performance through human resource management practice: from high potential employee's perspectives. Management Science Letters, 9, 1083-1092. doi: 10.5267/j.msl.2019.3.016

Oyeniyi, K.O., Adeyemi, M.A., \& Olaoye, B.O. (2017). Organizational commitment and employee's Job Performance: Evidence from Nigerian Hospitality Industry. International Journal of Innovative Psychology \& Social Development 5(3), 15-22.

Pang, K., \& Lu, C. S. (2018). Organizational motivation, employee job satisfaction and organizational performance: An empirical study of container shipping companies in Taiwan. Maritime Business Review, 3(1), 36-52.

Prasetya, A. \& Kato, M. (2011). The effect of financial and non-financial compensation to the employee performance. The 2nd International Research Symposium in Service Management. Yogyakarta, Indonesia.

Pratama, R., \& Aima, M. H. (2018). The effect of compensation and employee engagement on organizational commitments and its implementation toward employee's performance of Pt Xyz Jakarta. International Journal of Scientific and Research Publications, 8(12), 360-368. doi: 10.29322/IJSRP.8.12.2018.p8448

Pristiwati, M., \& Sunuharyo, B. S. (2018). PengaruhKomitmen, Organisasional dan Organizational Citizenship BehaviorterhadapKinerjaKaryawan (Studi Pada Karyawan PT PLN (Persero) Area Sidoarjo). JurnalAdministrasiBisnis, 61(4).

Purba, S. D., \& Ananta, A. N. D. (2018). The effects of work passion, work engagement and job satisfaction on turn over intention of the millennial generation. Jurnal Manajemen dan Pemasaran, 11(2), 263 - 274. doi: http://dx.doi.org/10.25105/jmpj.v11i2. 2954

Putri, W. H., \& Setianan, A. R. (2019). Job enrichment, organizational commitment, and intention to quit: the mediating role of employee engagement. Problems and Perspectives in Management, 17(2), 518-526. doi:10.21511/ppm.17(2).2019.40

Rai, A., Ghosh, P., Chauhan, R., \& Singh, R. (2018). Improving in-role and extra-role performances with rewards and recognition: does engagement mediate the process? Management Research Review, 41(8), 902-919.

Ramkissoon, H., \& Nunkoo, R. (2011). City image and perceived tourism impact: Evidence from Port Louis, Mauritius. International Journal of Hospitality and Tourism Administration, 12(2), 123-143.

Robberts, M. E., van der Poll, J.A. \& Engelbrecht, K. (2020). The impact of task-technology fit on the organisational commitment of mobile knowledge workers in South Africa. Proceedings of the South African Institute of Computer Scientists and Information Technologists (SAICSIT), 110-117, ACM Digital Library. doi: https://0-doiorg.oasis.unisa.ac.za/10.1145/3410886.3410897

Robbins, S. (2005). Organizational Behavior, 13th ed. New Jersey: Prentice Hall Inc.

Rohail, R., Zaman, F., Ali, F., Waqas, M., Mukhtar, M., \& Parveen, K. (2017). Effects of work environment and engagement on nurses' organizational commitment in Public Hospitals Lahore, Pakistan. Saudi Journal of Medical and Pharmaceutical Sciences, 3(7A), 748753. doi: $10.21276 /$ sjmps

Salim, M., Bakhit, A. \& Noor, N.A. (2017). The influence of organizational commitment on Omani public employees' work performance. International Review of Management and Marketing, 7(2), 151-160.

Schaufeli, W. (2012). Work engagement: An emerging psychological concept. In 30th International Congress on Occupational Health (March 18-23, 2012). Icoh.

Schaufeli, W. B., \& Bakker, A. B. (2004). Job demands, job resources, and their relationship with burnout and engagement: A multi-sample study. Journal of Organizational Behavior, 25(3), 293-315. 
Shahzadi, I. (2014). Impact of employee motivation on employee performance. European Journal of Academic Research in Business and Management, 6(23), 159-167.

Shuck, B., \& Wollard, K. (2010). Employee engagement and HRD: A seminal review of the foundations. Human Resource Development Review, 9, 89-110. doi: $10.1177 / 1534484309353560$

Singh, S. P., \& Karki, J. (2015). The impact of job engagement and organizational commitment on organizational performance. The International Journal of Business and Management, $3(2), 4$.

Sofiah, D., \& Kurniawan, G. H. (2019). Self-efficacy dengan work engagement pada karyawan. Jurnal Fenomena, 28(1), 54 - 61. doi: 10.30996/fn.v28i1.2641.

Suharto, S., \& Hendri, N. (2019). The impact of organizational commitment on job performance. International Journal of Economics and Business Administration, 7(2), 189-206.

Sweetman, D. \& Luthans, F. (2010). The power of positive psychology: psychological capital and work engagement", in Bakker, A.B. and Leiter, M.P. (Eds.), Work Engagement: A Handbook of Essential Theory and Research (pp. 54-68). Hove: Psychology Press.

Tnay, E., Othman, A.E., Siong, H.C., \& Lim, S. L. (2013). The influences of job satisfaction and organizational commitment on turnover intention. Journal of Social and Behavioral Sciences, 97, 201-208.

Tolentino, R.C. (2013). Organizational commitment and job performance of the academic and administrative personnel. International Journal of Information Technology and Business Management, 15(1), 51-59.

Wang, C. \& Chen, H. (2019). Relationships among workplace incivility, work engagement and job performance. Journal of Hospitality and Tourism, 3(4), 415-429. doi: 10.1108/JHTI09-2019-0105

Williams, L.J., \& Anderson, S.E. (1991). Job Satisfaction and Organizational Commitment as Predictors of Organizational Citizenship and In-role Behaviors. Journal of Management 17, 601-617.

World Health Organization (2020). Happy international Nurses Day. https://www.who.int/news/item/11-05-2020-happy-international-nurses-day

Xanthopoulou, D., Bakker, A. B., Demerouti, E., \& Schaufeli, W.B. (2007). The role of personal resources in the job demands-resources model. International Journal of Stress Management, 14(2), 121-141.

Xanthopoulou, D., Bakker, A. B., Demerouti, E., \& Schaufeli, W. B. (2009). Work engagement and financial returns: a diary study on the role of job and personal resources. Journal of Occupational and Organizational Psychology, 82(1), 183-200

Yousef, D. A. (2017). Organizational commitment, job satisfaction and attitudes toward organizational change: a study in the local government. International Journal of Public Administration, 40(1), 77-88. https://doi.org/10.1080/01900692.2015 .1072217 


\section{Appendix: Survey Questionnaire}

\section{Section A: Demographic Data}

This section provides information about you. Please tick as appropriate.

1. Gender: a. Male b. Female

2. Age: a. $18-25 \quad$ b. $26-30 \quad$ c. $31-35$ d. $36-40 \quad$ e. above 40

3. Qualification: a. Diploma b. BNSc c. Postgraduate d. Others

4. Employment: a. $0-5$ years b. $6-10$ years c. 10 - 15 years d. more than 15 years

\section{Section B: Research Question}

This section provides you with statements on affective commitment, continuance commitment, normative commitment, work engagement and job performance. Please tick as appropriate. Key to Options: 1 - Strongly Disagree; 2 -Disagree; 3 -Undecided; 4 -Agree; 5 - Strongly Agree

\begin{tabular}{|c|c|}
\hline \multicolumn{2}{|c|}{ Organisational Commitment } \\
\hline \multicolumn{2}{|r|}{ Affective Commitment } \\
\hline 1. & Being a member of this hospital makes me feel happy \\
\hline 2. & I feel good whenever I discuss my job with others outside it \\
\hline 3. & I really feel as if this hospital's problems are my own \\
\hline 4. & I hardly feel like "a member of the family" at this hospital \\
\hline 5. & I hardly feel "emotionally attached" to this hospital \\
\hline 6. & I think about this hospital every day \\
\hline \multicolumn{2}{|r|}{ Continuance Commitment } \\
\hline 1. & I am concerned about the loss of investment of my time and skills in this hospital \\
\hline 2. & If I was not working in this hospital, I would not feel good \\
\hline 3. & $\begin{array}{l}\text { My loyalty to this hospital is as a result of emotional, social and economic } \\
\text { investment made in it }\end{array}$ \\
\hline 4. & I always feel concerned about what I may likely lose with this hospital \\
\hline 5. & $\begin{array}{l}\text { Sometimes, it gives me concern what might happen if I cease to be a member of this } \\
\text { hospital }\end{array}$ \\
\hline 6. & I am not worried about leaving this hospital for something else \\
\hline \multicolumn{2}{|r|}{ Normative Commitment } \\
\hline 1. & I feel indebted to this hospital because of what I have benefited from it \\
\hline 2. & $\begin{array}{l}\text { My loyalty to this hospital cannot be compromised due to the fair treatment I have } \\
\text { received from it }\end{array}$ \\
\hline 3. & $\begin{array}{l}\text { If I was no longer a member of this hospital, my co-workers would be disappointed } \\
\text { in me }\end{array}$ \\
\hline 4. & $\begin{array}{l}\text { My loyalty to this hospital is as a result of similarity in my personal values and this } \\
\text { hospital's values }\end{array}$ \\
\hline 5 & I have belief in the mission of this hospital and I am committed to it \\
\hline 6. & This hospital has contributed favourably to my well-being \\
\hline
\end{tabular}




\begin{tabular}{|l|l|}
\hline \multicolumn{2}{|c|}{ Job Performance } \\
\hline 1. & I complete my given tasks \\
\hline 2. & I have the ability to fulfil the responsibilities of my job \\
\hline 3. & I do my job according to the formal job requirement \\
\hline 4. & $\begin{array}{l}\text { The activities I have engaged in so far in this hospital have influenced my nursing } \\
\text { job evaluation }\end{array}$ \\
\hline \multicolumn{2}{|l|}{$\quad$ Work Engagement } \\
\hline 1. & At this hospital, I feel energetic and able to do my tasks \\
\hline 2. & I have the capability to work for a very long period of time \\
\hline 3. & The work I do is meaningful and gives me a sense of purpose \\
\hline 4. & I am excited and proud about my work \\
\hline 5. & For me the work is quite challenging \\
\hline 6. & I have so much work to do every day \\
\hline
\end{tabular}




\section{Authors' Biographies}

Ismaheel Adewumi Raji is an M.Sc. scholar in Business Management at ABU Business School, Ahmadu Bello University, Zaria, Nigeria. A motivational speaker and Chief Executive Officer at Mollifier Educational, Research and HR Consulting, he has published a number of highly regarded articles both locally and internationally and presented influential papers at various academic conferences. His research areas cover HRM, Organisational Behaviour and Entrepreneurship. He is an author of the book titled Key Principles of Academic Excellence.

Md. Mahmudul Alam is an Associate Professor at Universiti Utara Malaysia. He is also an Associate Fellow at University Technology MARA (Malaysia). He was awarded the AFFP Research Fellowship from FS-UNEP Centre (Germany) and recognised by the BDRC (USA) as one of the "Top Bangladesh Development Researchers of the Millennium". He obtained his $\mathrm{PhD}$ and Master's degrees from the National University of Malaysia. To date he has published more than 140 articles in journals and presented more than 100 papers at conferences. His research areas include sustainable finance, sustainable development, ecological economics, financial economics, fintech, and Islamic finance and economics.

Sahnun Ladan is a Senior Lecturer in Business Management at ABU Business School, Ahmadu Bello University, Zaria, Nigeria. He holds a B.Sc. and an M.Sc. in Business Administration, from Ahmadu Bello University. He obtained his doctorate from the Universiti Utara Malaysia (UUM). He has two decades teaching and research experience and published several peer-reviewed papers and presented papers at several conferences on human resources and knowledge management. His research interests are organisational behaviour, knowledge management, and human resources management.

Ismail Tijjani Idris is a Senior Lecturer with the Department of Banking and Finance, ABU Business School of Ahmadu Bello University, Zaria, Nigeria. He obtained his PhD in Finance and Banking from the Universiti Utara Malaysia (UUM), while his M.Sc Business Administration and Master's in Business Administration (MBA) were obtained from Ahmadu Bello University, Zaria, Nigeria. He has worked for 14 years in banking and has published several articles in indexed journals and presented papers at numerous conferences. His research interests are financial stability, environmental finance, energy finance, business management processes, quality of bank assets, and risk management. 